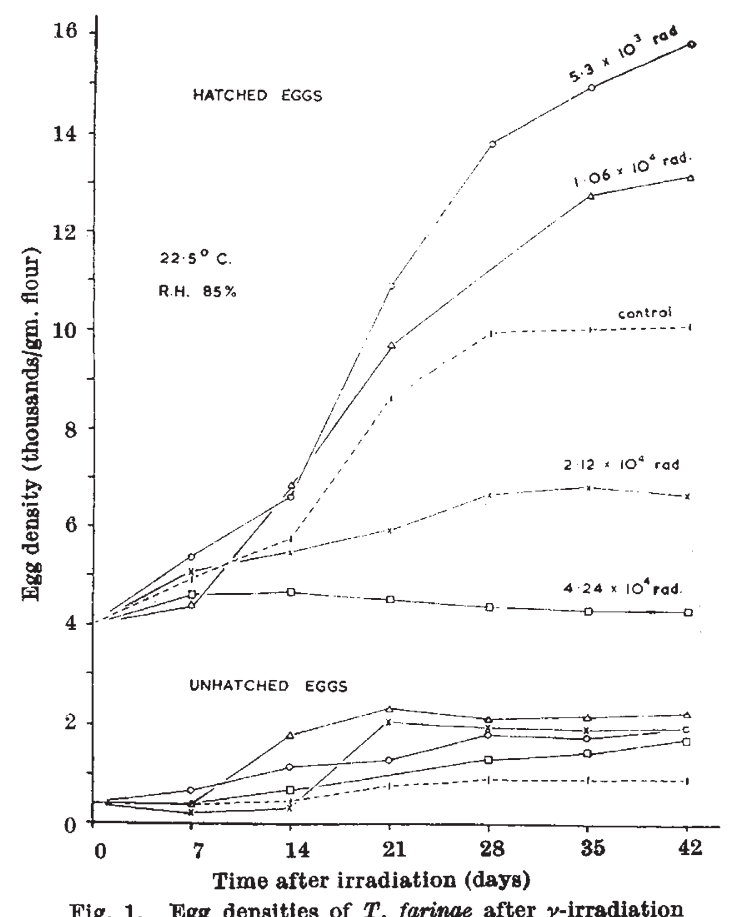

Fig. 1. Egg densities of $\boldsymbol{T}$. farinae after $\gamma$-irradiation

negligible after 28 days. In contrast, irradiation at $2 \times 10^{4}$ rad significently reduced the numbers of eggs laid and hatched and at $4 \times 10^{4} \mathrm{rad}$ hatching was negligible, although oviposition continued throughout the period. The total egg density indicated that $4 \times 10^{4}$ rad sterilized the population. With this organism, therefore, it was concluded that irradiation insufficient to sterilize may actually lead to an increase in the production of fertile eggs. These observations will be continued over longer periods.

Department of Pharmacy,

Colin MeLvilue

The University,
Manchester, 13 .

April 3.

${ }^{1}$ Cornwell, P. B., Crook, L. J., and Bull, J. O., Nature, 179, 670 (1957).

${ }^{2}$ Cork, J. M., Rad. Res., 7. 551 (1957).

${ }^{3}$ Melville, C., Bull. ent. Rez., 48, 723 (1957).

'Odum, E. P., "Fundamentals of Ecology" (Saunders, Philadelphia, 1953).

\section{Biochemical Differences between Inbred and Outbred lines of Drosophila melanogaster studied by Paper Partition Chromatography}

USING the techniques of paper chromatography described by Hadorn and Mitchell' ${ }^{1}$ and BuzzatiTraverso ${ }^{2}$, a study of the physiological processes of ageing of Drosophila melanogaster was undertaken in four stocks in which two systems of mating had been established. Two of these four stocks were highly inbred (404-407 generations for Oregon and 294-297 generations for Samarkand, with inbreeding broken at the hundredth generation by one generation of cousin-mating; Scossiroli, R., personal communication); the other two stocks, also of Samarkand and Oregon, were mass mated. The fluorescent compounds found are in agreement with those found by Hadorn and collaborators (personal communication).
During ageing of the mass-mated stocks a typical and constant patterm of nine fluorescent compounds is found. The inbred lines do not show. this constancy $^{8}$, and at any given stage appeared to lack some fluorescent compounds. We were able to determine that at least five of the nine compounds were affected in some way by the inbreeding level of our stocks. The compounds were: xanthopterin ${ }^{4}$ (our green spot, No. 4) ; spot No. 6 (possibly a complex of two compounds ${ }^{5}$; spot No. 8 (our blue spot; kynurenin"); and spot No. 9, which appesers in small amounts. Inbreeding tended to eliminate or conceal these compounds, and also revealed its effects on the processes of ageing of our inbred stocks by decreasing the fluorescence of these compounds when they were present. In this respect fluorescence of kynurenin from inbred females and that of isoxanthopterin? were affected considerably. The presence of kynurenin in the eggs of Drosophila has been demonstrated by others'. Inbreeding, therefore, seems to have affected the 'normal' occurrence of this compound in the females of our stocks.

Recent work by Robertson and Forrest8 has also demonstrated that there is a very significant difference in isoxanthopterin between inbred and wild stocks of Drosophila.

We consider the low fluorescence in the compounds mentioned in Table 1 to be indicative of the effects of inbreeding on the general process of ageing in Drosophila melanogaster. The uniform and strong fluorescence displayed by the outbred stocks of this species can be interpreted as resulting from well 'canalized's ageing processes.

\begin{tabular}{|c|c|c|c|c|c|c|}
\hline Stocks & $\begin{array}{l}\text { Spot } \\
\text { No. }\end{array}$ & $\boldsymbol{n}$ & $\begin{array}{c}\text { Fluor- } \\
\text { escence } \\
\text { (arbi- } \\
\text { trary } \\
\text { units) }\end{array}$ & $\stackrel{t}{t}$ values & $\begin{array}{l}\text { Degrees } \\
\text { of } \\
\text { freedom }\end{array}$ & $\begin{array}{l}99 \text { per } \\
\text { cent con- } \\
\text { fldence }\end{array}$ \\
\hline 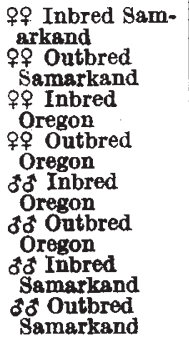 & $\begin{array}{l}8 \\
8 \\
8 \\
8 \\
3 \\
3 \\
3 \\
3\end{array}$ & $\begin{array}{l}22 \\
22 \\
26 \\
26 \\
27 \\
27 \\
16 \\
16\end{array}$ & $\begin{array}{l}50 \cdot 04 \\
76 \cdot 45 \\
58 \cdot 00 \\
88 \cdot 00 \\
70 \cdot 77 \\
93 \cdot 00 \\
76 \cdot 14 \\
70 \cdot 12\end{array}$ & $26 \cdot 08$ & 25 & $\begin{array}{l}\text { very sig- } \\
\text { niflcant } \\
\text { very sig- } \\
\text { niffesnt } \\
\text { very sig- } \\
\text { nifleant }\end{array}$ \\
\hline
\end{tabular}

We wish to thank Prof. C. Barigozzi for his advice. The award of a Comitato Nazionale per la Ricerca Nucleare Ispra Research Fellowship to the senior author is gratefully acknowledged.

H. F. HoEnigsberg

M. C. Castigliont

Institute of Genetics,

University of Milan. March 3.

1 Hadorn, E., and Mitchell, H. K., Proc. U.S. Nat. Acad. Sci., 37, 650 (1951).

2 Buzzati-Traverso, A. A., Proc. U.S. Nat. Acad. Sci., 39, 378 (1953).

${ }_{3}^{3}$ Hoenigsberg, H. F., and Castiglioni, M. C. (in the press).

4 Hadorn, E., and Ziegler (in the press).

${ }^{5}$ Forrest, H., and Mitchell, H. K., J. Amer. Chem. Soc., 77, 4865 (1955). Viscontini, M., Schoeller, M., Loeser, E., Karrer, P., and Hadorn, E., Helv.'Chim. Acta,, 88397 (1955).

- Danneel, R., and Zimmermann, B., Z. Naturf., 96 (1954).

' Hadorn, E., and Schwinck, I., Z. Vererbungslehre, 87, 528 (1956). Hadorn, E., Experientia, 10, 483 (1954).

8 Robertson, F. W., and Forrest, H. S., Univ. of Texas Pub. 5721, 229 (1957).

- Lerner, M., "Genetic Homeostasis" (Oliver and Boyd, 1954). 